\title{
The Reflective Teaching Log (RTL): Effective Documentation of Participatory Teaching Requirements
}

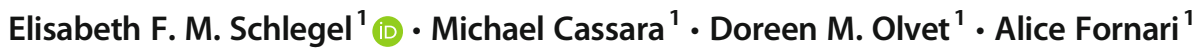 \\ Published online: 5 March 2019 \\ (C) The Author(s) 2019
}

\begin{abstract}
We created a reflective teaching log for a student-as-teacher elective to track students' required participatory teaching and to provide a mechanism for reflective evaluation. This Minute Paper-based log is easy to use and can be adapted to similar programs capturing insights of students' teaching experiences and supports reflective learning.
\end{abstract}

Keywords Teaching $\log \cdot$ Reflection $\cdot$ Medical education elective $\cdot$ Course requirement

The professional development of medical students has expanded to include a role as an educator. As future physicians, they will be expected to teach medical students and residents both during residency training and as faculty physicians in a university hospital setting. Recognizing this, at least $44 \%$ of medical schools now offer medicalstudent-as-teacher (MST) programs [1]. These programs traditionally include peer or near-peer teaching as well as didactic sessions on the knowledge and skills that are essential to become effective teachers [2]. However, MST students do not necessarily receive feedback from faculty on their teaching performance [2]. A mechanism should be in place to record teaching experiences and allow for an exchange of reflective feedback with the course director about each teaching encounter.

The practice of reflective writing can promote learning through transformation of experience into abstract conceptualization and insights followed by application [3]. Reflective logs have been used to document student

Elisabeth F. M. Schlegel

Elisabeth.Schlegel@Hofstra.edu

1 Donald and Barbara Zucker School of Medicine at Hofstra/ Northwell, Hempstead, NY, USA experiences during clinical teaching and learning sessions [4]. Data from these student reflections indicate that medical students develop teaching skills, self-confidence, and a professional identity as a medical educator [4]. However, these findings are limited because it may not be practical to gather lengthy reflections after all pivotal teaching experiences [4]. One solution is to incorporate brief Minute Paper elements within a participatory teaching requirement $\log$ [5]. The Minute Paper is an assessment technique that allows learners to briefly reflect on and assess their understanding of the material [5].

We developed a brief Reflective Teaching Log (RTL) as a part of our MST elective course offered in the fourth year at the Zucker School of Medicine at Hofstra/Northwell. The MST course is longitudinal and consists of a combination of didactic lectures, workshops, journal club sessions, and a summative capstone project. In addition, students are required to complete $20 \mathrm{~h}$ of self-selected teaching, which is documented in the RTL. The RTL was created in Microsoft Excel and is made available to students electronically and stored in a cloud-based platform (e.g., Google docs). Each student shares a link with the Course Directors. This shared spreadsheet streamlined the communication process between students and faculty by allowing for real-time data sharing on their teaching experiences. Students are required to complete the $\log$ for each teaching experience including logistical 
REFLECTIVE TEACHING LOG RTL

\begin{tabular}{|c|c|c|c|c|c|c|c|c|}
\hline MEDICAL PEDAGOGY & DATE & $\begin{array}{l}\text { \# OF } \\
\text { HOURS }\end{array}$ & FACILITATOR & MY ROLE & INSIGHTS, REFLECTIONS \& FURTHER ACTIONS & $\begin{array}{l}\text { MOST IMPORTANT } \\
\text { CONCEPT LEARNED }\end{array}$ & $\begin{array}{l}\text { CONCEPT REQUIRING } \\
\text { CLARIFICATION }\end{array}$ & $\begin{array}{l}\text { WHAT IS APPLICABLE TO } \\
\text { YOUR FUTURE ROLE AS A } \\
\text { RESIDENT }\end{array}$ \\
\hline \multicolumn{9}{|l|}{ 1. CASE-BASED LEARNING } \\
\hline $\begin{array}{l}\text { Case-based Session for accepted } \\
\text { Students; Pre-matriculation Program }\end{array}$ & $1 / 8 / 18$ & 2 & Facilitator 1 & Facilitator & $\begin{array}{l}\text { Facilitating a case for novices needs attentive listening skills. } \\
\text { When wrapping up the session, students appreciated the } \\
\text { encouragement to share their experience. }\end{array}$ & $\begin{array}{l}\text { Allow silence to encourage deep } \\
\text { thinking. }\end{array}$ & $\begin{array}{l}\text { Walking students through case } \\
\text { analysis without prior knowledge } \\
\text { requires creative thinking and } \\
\text { examples from real life. }\end{array}$ & $\begin{array}{l}\text { Creativity and out-of the box } \\
\text { thinking are key when } \\
\text { teaching others. }\end{array}$ \\
\hline 2. LARGE GROUP SESSION & DATE & \# OF HOURS & LECTURER & MY ROLE & INSIGHTS, REFLECTIONS \& FURTHER ACTIONS & $\begin{array}{l}\text { MOST IMPORTANT CONCEPT } \\
\text { LEARNED }\end{array}$ & $\begin{array}{l}\text { CONGEPT REQUIRING } \\
\text { CLARIFICATION }\end{array}$ & $\begin{array}{l}\text { WHAT IS APPLICABLE TO } \\
\text { YOUR FUTURE ROLE AS A } \\
\text { RESIDENT }\end{array}$ \\
\hline $\begin{array}{l}\text { Cultural Competency: Visual Impaired, } \\
\text { Deaf, } \mathrm{HOH}\end{array}$ & $2 / 8 / 18$ & 2 & Facilitator 2 & Student observer & $\begin{array}{l}\text { Discussion with patients is an excellent modality to offer } \\
\text { different perspectives and answer questions. }\end{array}$ & $\begin{array}{l}\text { Using small-group break-out } \\
\text { activities during large group } \\
\text { sessions invigorates a session. }\end{array}$ & $\begin{array}{l}\text { How to deliver faculty } \\
\text { development to guest lecturers. }\end{array}$ & $\begin{array}{l}\text { Conducting large group } \\
\text { sessions in a medical school } \\
\text { setting. }\end{array}$ \\
\hline $\begin{array}{l}\text { 3. INTEGRATIVE ANATOMY } \\
\text { LABORATORY }\end{array}$ & DATE & \# OF HOURS & FACILITATOR & MY ROLE & INSIGHTS, REFLECTIONS \& FURTHER ACTIONS & $\begin{array}{l}\text { MOST IMPORTANT CONCEPT } \\
\text { LEARNED }\end{array}$ & $\begin{array}{l}\text { CONCEPT REQUIRING } \\
\text { CLARIFICATION }\end{array}$ & $\begin{array}{l}\text { WHAT IS APPLICABLE TO } \\
\text { YOUR FUUURE ROLE AS A } \\
\text { RESIDENT }\end{array}$ \\
\hline $\begin{array}{l}\text { Female Reproductive Anatomy with } \\
\text { Ultrasound }\end{array}$ & $3 / 8 / 18$ & 5 & Facilitator 3 & MS4 Co-Facilitator & $\begin{array}{l}\text { Working alongside faculty allows tuning into one another's } \\
\text { teaching. It is very enjoyable and requires keen attention. }\end{array}$ & $\begin{array}{l}\text { Team teaching allows providing } \\
\text { complementary content, such as } \\
\text { clinical pearls. }\end{array}$ & $\begin{array}{l}\text { Most effective way of teaching } \\
\text { ultrasound. }\end{array}$ & $\begin{array}{l}\text { Effective team teaching of } \\
\text { content combining basic and } \\
\text { clinical science. }\end{array}$ \\
\hline 4. SIMULATION & DATE & \# OF HOURS & FACILITATOR & MYROLE & INSIGHTS, REFLECTIONS \& FURTHER ACTIONS & $\begin{array}{l}\text { MOST IMPORTANT CONCEPT } \\
\text { LEARNED }\end{array}$ & $\begin{array}{l}\text { CONCEPT REQUIRING } \\
\text { CLARIFICATION }\end{array}$ & $\begin{array}{l}\text { WHAT IS APPLICABLE TO } \\
\text { YOUR FUTURE ROLE AS A } \\
\text { RESIDENT }\end{array}$ \\
\hline $\begin{array}{l}\text { Standardized Learner for SP Writing } \\
\text { Course }\end{array}$ & $1 / 17 / 18$ & 3.5 & Facilitator 4 & Standardized Learner & $\begin{array}{l}\text { Standardized patients are highly trained experts, and } \\
\text { interacting with them reveals important insights relevant for } \\
\text { the case and the learner. }\end{array}$ & $\begin{array}{l}\text { It is so important to thoroughly } \\
\text { understand the goals of the case } \\
\text { and the nuances displayed. }\end{array}$ & $\begin{array}{l}\text { Aligning the session plan with the } \\
\text { Simulation Center policies was not } \\
\text { explained well. }\end{array}$ & $\begin{array}{l}\text { Collaborating with the } \\
\text { Simulation Center in } \\
\text { implementing a case session }\end{array}$ \\
\hline 5. CLINICAL SKILLS/ PD SESSION & DATE & \# OF HOURS & FACILITATOR & MY ROLE & INSIGHTS, REFLECTIONS \& FURTHER ACTIONS & $\begin{array}{l}\text { MOST IMPORTANT CONCEPT } \\
\text { LEARNED }\end{array}$ & $\begin{array}{l}\text { CONCEPT REQUIRING } \\
\text { CLARIFICATION }\end{array}$ & $\begin{array}{l}\text { WHAT IS APPLICABLE TO } \\
\text { YOUR FUTURE ROLE AS A } \\
\text { RESIDENT }\end{array}$ \\
\hline $\begin{array}{l}\text { Physical Diagnosis Session: } \\
\text { Cardiovascular Exam }\end{array}$ & $7 / 12 / 17$ & 1.5 & Facilitator 5 & MS4 Co-Facilitator & $\begin{array}{l}\text { Tailor instructions to individual needs and student levels, and } \\
\text { approach students at the right time for instruction. Not so } \\
\text { long ago I was at the same level and feel I can relate to } \\
\text { students' needs. I hope that hightens my sensitivity towards } \\
\text { younger students' learning needs. }\end{array}$ & $\begin{array}{l}\text { Using a flowchart for developing } \\
\text { differential diagnosis. }\end{array}$ & $\begin{array}{l}\text { When to interrupt a student group } \\
\text { to support learning, and when to } \\
\text { wait to allow students discover } \\
\text { the concepts on their own. }\end{array}$ & $\begin{array}{l}\text { Clinical reasoning is a key } \\
\text { aspect of medical education. } \\
\text { It will be important for me as } \\
\text { a resident for teaching of } \\
\text { residents below me as well } \\
\text { as medical students rotating } \\
\text { through. }\end{array}$ \\
\hline 6. SMALL GROUP & DATE & \# OF HOURS & FACILITATOR & MY ROLE & INSIGHTS, REFLECTIONS \& FURTHER ACTIONS & $\begin{array}{l}\text { MOST IMPORTANT CONCEPT } \\
\text { LEARNED }\end{array}$ & $\begin{array}{l}\text { CONCEPT REQUIRING } \\
\text { CLARIFICATION }\end{array}$ & $\begin{array}{l}\text { WHAT IS APPLICABLE TO } \\
\text { YOUR FUTURE ROLE AS A } \\
\text { RESIDENT }\end{array}$ \\
\hline Interacting with Industry & $1 / 24 / 18$ & 3 & Facilitator 6 & MS4 Co-Facilitator & $\begin{array}{l}\text { Consistency in education is so important....... appreciated } \\
\text { being able to work with the same small group for each of the } \\
3 \text { sessions. Enhanced learning through relationship. }\end{array}$ & $\begin{array}{l}\text { Assigning roles in small group } \\
\text { sessions. }\end{array}$ & $\begin{array}{l}\text { Identifying and liaisoning with } \\
\text { industry leaders. }\end{array}$ & $\begin{array}{l}\text { Importance of establishing } \\
\text { rapport and relationships. } \\
\text { Ensure to address students } \\
\text { by their names. }\end{array}$ \\
\hline 7. CLINICAL TEACHING UPON REQUEST & DATE & \# of Hours & FACILTATOR & MY ROLE & INSIGHTS, REFLECTIONS \& FURTHER ACTIONS & $\begin{array}{l}\text { MOST IMPORTANT CONCEPT } \\
\text { LEARNED }\end{array}$ & $\begin{array}{l}\text { CONCEPT REQUIRING } \\
\text { CLARIFICATION }\end{array}$ & $\begin{array}{l}\text { WHAT IS APPLICABLE TO } \\
\text { YOUR FUTURE ROLE AS A } \\
\text { RESIDENT }\end{array}$ \\
\hline Clinical Learning Skills & $2 / 13 / 18$ & 3 & Facilitator 7 & MS4 Co-Facilaitator & Step back and allow students to lead a session. & $\begin{array}{l}\text { Ensuring students are } \\
\text { comfortable with the content } \\
\text { and voice questions aloud before } \\
\text { the role-play starts. }\end{array}$ & $\begin{array}{l}\text { How to adjust complexity of } \\
\text { material to learning needs? }\end{array}$ & $\begin{array}{l}\text { Working on how to explain } \\
\text { material in a clear way, or } \\
\text { identifying a peer-teacher. }\end{array}$ \\
\hline \multirow[t]{2}{*}{ 8. OTHER UPON REQUEST } & DATE & \# of Hours & FACILTATOR & MY ROLE & INSIGHTS, REFLECTIONS \& FURTHER ACTIONS & $\begin{array}{l}\text { MOST IMPORTANT CONCEPT } \\
\text { LEARNED }\end{array}$ & $\begin{array}{l}\text { CONCEPT REQUIRING } \\
\text { CLARIFICATION }\end{array}$ & $\begin{array}{l}\text { WHAT IS APPLICABLE TO } \\
\text { YOUR FUTURE ROLE AS A } \\
\text { RESIDENT }\end{array}$ \\
\hline & $1 / 23 / 18$ & 1 & Facilitator 8 & Student Group facilitator & $\begin{array}{l}\text { Creating an atmosphere of trust is paramount. Step back from } \\
\text { your own plan to allow others to settle into a scenario. }\end{array}$ & $\begin{array}{l}\text { Expect surprising reactions and } \\
\text { be ready to comfort. Give others } \\
\text { a space for their own reaction. }\end{array}$ & $\begin{array}{l}\text { When to interrup silence to drive } \\
\text { a difficult conversation. }\end{array}$ & $\begin{array}{l}\text { Leading discussion groups for } \\
\text { giving difficult news for } \\
\text { fellow residents, attendings } \\
\text { and students. }\end{array}$ \\
\hline
\end{tabular}

Fig. 1 Reflective Teaching Log RTL

information, educational setting they taught, pedagogy employed, the number of hours taught, their role, and their faculty supervisor. In addition, the major portion of the RTL is comprised of elements of the Minute Paper, such as "most important concept learned," or "concept requiring clarification" (see Fig. 1, simulated Reflective Teaching Log RTL). These columns prompt students to briefly reflect on their experience more broadly, asking them to describe any insights gained, the most important concept they learned, what they needed clarification on, and what specific skill they will take away from the experience. The logs also provided important program related feedback, such as which sessions or pedagogies were most valuable to learners and the diversity of teaching sessions selected.

The RTL is an ideal tool for tracking student teaching and reflective experiences without being overly burdensome for the student or Course Director. It can easily be adapted to different educational settings, and individual variables can be tailored to specific course objectives. We encourage other medical schools to utilize the RTL to track program outcomes quantitatively and qualitatively. The outcomes will ultimately improve curricula focused on training MSTs.
Acknowledgments The authors would like to thank Kevin Brian D. McLeod, AdTalem Global Education, Chicago, for technical assistance editing the teaching log, and Wendy Saori Herman for expert assistance with references. A big thank you to our students who are using the RTL.

\section{Compliance with Ethical Standards}

Conflict of Interest The authors declare that they have no conflict of interest.

Ethical Approval This study was approved by the institutional review board for human subjects review studies.

\section{Informed Consent NA}

Open Access This article is distributed under the terms of the Creative Commons Attribution 4.0 International License (http:// creativecommons.org/licenses/by/4.0/), which permits unrestricted use, distribution, and reproduction in any medium, provided you give appropriate credit to the original author(s) and the source, provide a link to the Creative Commons license, and indicate if changes were made.

Publisher's Note Springer Nature remains neutral with regard to jurisdictional claims in published maps and institutional affiliations. 


\section{References}

1. Soriano RP, Blatt B, Coplit L, Cichoski Kelly E, Kosowicz L, Newman L, et al. Teaching medical students how to teach: a national survey of students-as-teachers programs in US medical schools. Acad Med. 2010;85(11):1725-31.

2. Marton GE, McCullough B, Ramnanan CJ. A review of teaching skills development programmes for medical students. Med Educ. 2015;49(2):149-60.
3. Kolb DA. Experiential learning: experience as the source of learning and development: FT press; 2014.

4. Freeman M. Reflective logs: an aid to clinical teaching and learning. Int J Lang Commun Disord. 2001;36(sup1):411-6.

5. Angelo TA, Cross KP. Classroom assessment techniques: a handbook for faculty. Ann Arbor: National Center for Research to Improve Postsecondary Teaching and Learning; 1993. 